\title{
Climate and Water Resources in the Carolinas: Approaches to Applying Global Climate Change Information to Local Decisions
}

\author{
Kirsten Lackstrom, Gregory J. Carbone, Daniel L. Tufford, Aashka Patel
}

AUTHORS: Carolinas Integrated Sciences \& Assessments (CISA), University of South Carolina, Columbia, SC 29208, USA.

\begin{abstract}
A wide range of resource managers, community planners, and other stakeholders are increasingly asking for information regarding how climate change will affect South Carolina's freshwater and coastal resources. They are interested in using this information for decisions related to infrastructure design, water system planning, vulnerability assessments, and ecosystem management. While climate change data, projections, and related information are also becoming increasingly available, many uncertainties around future climate change and its potential impacts often hinder its application. Furthermore, it is often not available in a format or at a scale that is easily translated to local- and regional resource management decisions. This article highlights decision-maker questions about climate change in the Carolinas, approaches to using global climate change information, and opportunities to bridge the gap that often exists between scientific research and applications. We find that integration of future climate scenarios with water resources issues succeeds when robust links exist between climate variables and system response, and when scenarios from observed or simulated climate data are representative, plausible, and consistent. In general, there is no one "best" model that depicts future climate conditions, nor can climate science provide accurate predictions for specific locations and impacts. However, climate change projections can be used in conjunction with a variety of other tools and resources, such as vulnerability assessments and historical climate observations, to inform planning processes. Improved understanding of the system of concern, the linkages to climate, and the most important variables can help decision makers and researchers alike to develop the most relevant and informative analyses for climate-related questions. Ongoing engagement, as well as a willingness to experiment and share lessons learned, between and across the resource management and science communities will help to advance the climate change dialogue in the Carolinas and enhance the production and use of climate change information.
\end{abstract}

\section{INTRODUCTION}

Recent droughts, floods, and tropical storms in the Carolinas have exposed vulnerabilities of the region's water resources to climate events. Climate also interacts with other stressors experienced in the southeastern United States such as rapid urbanization, land use change, and population growth (see for example, Nagy et al., 2011; Sanger et al., 2015; Terando et al., 2014). Water-related concerns frequently stem from the impacts these stressors have on current water availability and quality for both human and natural systems. Increasingly, a wide range of decision makers are also asking for tailored information regarding how climate change will affect South Carolina's freshwater and coastal resources in the future. Temperatures are expected to increase across the Southeast, with the greatest warming projected to occur in the summer. Significant increases in the number of hot days $\left(\geq 95^{\circ} \mathrm{F}\right)$ are also expected. However, there is less certainty about future precipitation patterns, including the frequency and intensity of rainfall events and tropical storms. Although many climate models do project increasing precipitation, higher temperatures and increasing water demands alone could adversely affect water availability (Ingram et al., 2013).

Various organizations and agencies are beginning to consider future climate risks in resource assessments and planning. South Carolina examples include the Francis Marion National Forest Draft Revised Land Management Plan (USDA, 2015) and the State's 2015 State Wildlife Action Plan (SC DNR, 2014). However, several challenges can hinder the incorporation of climate change information into many planning and management processes. For example, in the Southeast, one challenge involves the complexities and uncertainties related to the magnitude and direction of climate change. Although climate models can provide information relevant to the regional scale, there is uncertainty regarding how to translate this information to the local level, how to apply climate model output to specific decisions such as those related to water supply, and what are the most appropriate tools and resources for different contexts (Barsugli et al., 2012; Brown and Wilby, 2012; Kiparsky et al., 2012; Mote et al., 2016). 
The intent of this article is to illustrate both the challenges and opportunities associated with managing uncertainties related to climate change. It draws from work conducted by the Carolinas Integrated Sciences \& Assessments (CISA) program. ${ }^{1} \mathrm{CISA}$ is an interdisciplinary program that conducts use-inspired, applied research with two objectives in mind. The first objective is to advance scientific understanding of the processes of climate variability and change and related impacts in the Carolinas. Much of CISA's research has focused on climate interactions with water resources, human health, and coastal issues. The second objective is to provide decision support through the development of targeted tools and processes to facilitate the use of climate information in planning and management decisions. The article focuses on the methods used by the CISA team to answer climate change questions. By reflecting on our experiences, we hope to illuminate the processes through which researchers and decision makers can work together to better understand and improve the resilience of South Carolina's water resources to climate variability and change.

We begin the article by reviewing some of the challenges both climate information providers and users face in considering climate change questions. We then highlight several Carolinas-specific questions about climate change and the challenges emerging from this work. We conclude the article by offering suggestions for advancing climate dialogue in the Carolinas.

\section{CLIMATE CHANGE INFORMATION FOR DECISION MAKING}

The assessment and management of climate risks are critical components of water resources management and planning. Climate information is used to inform activities and decisions that occur on a variety of time frames. Examples include the design of water infrastructure and delivery systems, coordination of water releases from multi-use reservoir projects, wildlife refuge management, and development of monitoring and response protocols to address specific risks such as those related to flooding, intense drought, or wildfire (Lackstrom et al., 2014). While resource managers in the Carolinas have adapted to the considerable climate variability the region experiences, scientists and decision makers alike have questions about future climate variability and change. Producing information in order to support planning for the potential effects of climate change, and for specific management decisions, can be difficult (McNie et al., 2016). Likewise, for information users, navigating through the plethora of increasingly available climate change information can be a challenge.

One challenge, shared by information producers and users, is that the complexities and uncertainties related to climate change are often difficult to communicate, characterize, and understand. In addition, scientists and decision makers have different perspectives in approaching

${ }^{1}$ Information about CISA is available at http://www.cisa.sc.edu/. uncertainty. Scientists often use uncertainty as the impetus for research. Scientific investigation might succeed in improving understanding of a particular phenomenon, but might also reveal new sources of uncertainty that warrant further study (Lemos and Rood, 2010; McNie et al., 2016). Decision makers typically approach uncertainty as a risk management question aimed at reducing potential harm or losses (Travis and Bates, 2014). Improving the understanding of the variety of uncertainties associated with climate change, and bridging the gaps between research and applications, are critical activities for scientists and resource managers, i.e., those who are assessing climate risks and making water resources decisions (Dessai and Hulme, 2007).

Over the past twenty-five years, research efforts to identify and develop best practices regarding the provision of climate decision support have grown. "Climate decision support" refers to the process of producing useful and relevant climate information for the users of that information. This process entails engagement between scientists and decision makers to assess climate-related problems and identify what information or resources can help to address those problems. In cases where existing information is not useful, efforts frequently focus on providing new syntheses or analyses or developing new tools to meet decisionmaking needs (Moss et al., 2014; NRC 2009). But, despite advances and efforts to communicate the potential benefits and limits of climate change information, users (or potential users) of this information often have misconceptions about its use and usefulness. One misconception is that climate projections can forecast future climate conditions accurately and at precise spatial and temporal scales. On the other end of the spectrum, decision makers may perceive that the uncertainties associated with climate models are too great to inform decisions, thereby explaining inaction in considering climate change (Briley et al., 2015; Kiparsky et al., 2012; Lemos and Rood, 2010; Snover et al., 2013).

Efforts to provide useful climate change information continue to evolve as we refine understanding of the most effective ways for climate scientists and information users to work together to identify needs and apply new information. Here we briefly discuss approaches, and associated challenges, to answering climate change questions.

\section{Approaches to Using Climate Change Information}

A "top-down" approach has evolved as the scientific community has sought to answer societal questions regarding climate change. Top-down strategies involve the development of climate projections, based on general circulation models (GCMs) of Earth's atmosphere, to estimate impacts of future climate change. GCMs represent our most sophisticated means of simulating the climate system and of measuring climate responses to changing radiative forcing (e.g., that imposed by increasing greenhouse gases) and can replicate major features of mean climate very well (Carbone, 2014). However, the application of GCM output to decisions faces many challenges (Wilby and Dessai, 2010). First, global models can only treat some 
atmospheric processes explicitly, must use estimates of future greenhouse gas emissions, and have a range of climate sensitivity to radiative forcing changes (Carbone, 2014). Second, GCMs were not designed to produce projections for specific regions or short time periods. Other factors that affect climate vulnerability, such as the localized and indirect impacts of climate, and future policies and human responses to climate, are difficult to integrate into GCMs (Dessai and Hulme, 2007; Pidgeon and Fischoff, 2011). This contributes to a "cascade of uncertainty" regarding the suite of decisions that are made during GCM design, including how different climate processes are included and parameterized, and the subsequent use of GCM output (Wilby and Dessai, 2010).

Recognizing the uncertainties in these models, researchers have sought to develop ways to address them appropriately. One widespread approach is the use of an "ensemble" of climate projections, wherein output from a suite of models produces a model average, or preferably, a range of values that can be used to characterize plausible climate change scenarios. The spread of different models provides an inherent measure of confidence associated with a particular variable for a particular region and timeframe. To address the issue of scale, output is often "downscaled" from standard model output to a more appropriate scale. Downscaled climate change projections have been made available for North America, and for the globe, by many different research groups using a range of approaches (Jacob et al., 2014; Mearns, et al., 2012).

The ongoing development of climate models is valuable for improving understanding of the climate system and potential future changes (Brown and Wilby, 2012). However, research also reveals that focusing narrowly on providing new information or reducing scientific uncertainty is not enough. From a decision-maker perspective, for example, global climate change information often does not "fit" into their decision context. Information might not be available at the appropriate spatial or temporal scale, easily accessible, or in a format that is understandable and usable (Dilling and Lemos, 2011; Dow et al., 2009). GCMs will likely improve with time, but their application for climate-related decisions will demand new approaches that recognize and address their uncertainties.

For example, climate impacts on society and the environment often involve a range of variables and time frames that climate models do not simulate well (Mote et al. 2016). Improved understanding of the system (e.g., a water supply system, ecosystem) of concern, as well as its linkages to climate, can help identify the climate variables of interest for that particular system and which models or tools might be most applicable. Increasingly, decision makers are also questioning the extent to which future climate will exhibit nonstationarity and suitability of existing performance measures (Brown, 2010). Since the assumption of stationarity underlies the design and management of many water infrastructure systems, the challenge for water managers will be developing new and robust methods to plan for future climate conditions (Brown, 2010; Milly et al., 2007).
"Bottom-up" approaches start by assessing a system's (or an action's) vulnerabilities and coping capacity, rather than with climate model scenarios. The ultimate goal is to identify strategies whose performance is robust across a wide range of possible futures. For example, the decision-scaling or scenario-neutral framework emphasizes evaluating, first, a system's sensitivity to changes in climate conditions and the magnitude of changes that make the system vulnerable (or cause it to fail), before assessing the plausibility of these vulnerability-inducing climate conditions (i.e., "critical climate conditions") as indicated by climate change projections (Brown et al., 2012). A system's vulnerability is based on "critical decision thresholds." Hence, critical climate conditions are those that change the system's performance beyond an acceptable threshold and, as a result, suggest the need for an alternative course of action. Conducting vulnerability analysis first often reveals relationships between a system's performance and climate variables, which can help tailor climate change projections (Barsugli et al. 2012; Brown et al., 2012; Stainforth et al., 2007). This process can then help inform the selection of GCMs, other climate information, or related resources to support further analysis and assessment (Brown and Wilby, 2012; Snover et al., 2013). Such a process also allows decision makers to consider climate vulnerabilities, and use climate change information, even when many uncertainties remain unresolved (Weaver et al., 2013).

\section{CLIMATE CHANGE IN THE CAROLINAS: QUESTIONS AND UNCERTAINTIES}

This section discusses examples of specific decisionmaker climate change concerns and questions from the Carolinas. Decision maker questions often relate to one, how water and ecological resources will respond to future climate change and two, how information from climate change projections can be effectively used for management and planning decisions. Under each question we elaborate on the context in which an information user (e.g., water or natural resource manager, extension program, or other researcher) requested climate information. We briefly describe CISA's role in providing climate information and then highlight the different types and sources of uncertainty that emerged and the associated challenges they posed to the provision of climate change information. In some examples, CISA initiated subsequent research to further investigate these questions. Table 1 summarizes decision-maker and researcher questions and the key uncertainties and challenges associated with each.

To what extent will future climate conditions affect precipitation intensity, duration and frequency?

A National Estuarine Research Reserve (NERR) System Science Collaborative grant supported a collaboration between the ACE Basin and North Inlet-Winyah Bay NERRs, the Center for Watershed Protection, South Carolina Sea 
Table 1. Decision-maker and researcher questions, uncertainties, and challenges regarding climate change.

\begin{tabular}{|c|c|c|c|c|}
\hline $\begin{array}{l}\text { Motivation or } \\
\text { core issue }\end{array}$ & Decision-maker questions & Climate uncertainty & Researcher questions & $\begin{array}{l}\text { Researcher } \\
\text { challenges }\end{array}$ \\
\hline \multirow{2}{*}{$\begin{array}{l}\text { Stormwater } \\
\text { management and } \\
\text { guidance for low } \\
\text { impact development } \\
\text { strategies in coastal } \\
\text { areas }\end{array}$} & $\begin{array}{l}\text { To what extent will future } \\
\text { climate conditions affect water } \\
\text { elevations and precipitation } \\
\text { intensity, duration, and } \\
\text { frequency? }\end{array}$ & \multirow{2}{*}{$\begin{array}{l}\text { Climate system } \\
\text { response to changing } \\
\text { land, ocean, and } \\
\text { atmospheric } \\
\text { conditions }\end{array}$} & $\begin{array}{l}\text { How do models perform in } \\
\text { simulating historic extreme } \\
\text { rainfall events? } \\
\text { How can models be used to } \\
\text { investigate future changes in } \\
\text { rainfall patterns? }\end{array}$ & $\begin{array}{l}\text { Climate model } \\
\text { projection uncertainty }\end{array}$ \\
\hline & $\begin{array}{l}\text { To what extent is stationarity } \\
\text { a valid assumption for } \\
\text { stormwater risk assessment and } \\
\text { management? }\end{array}$ & & $\begin{array}{l}\text { What is the sensitivity of } \\
\text { design storm magnitude and } \\
\text { frequency to the length and } \\
\text { period of record? }\end{array}$ & $\begin{array}{l}\text { Uncertainty in } \\
\text { the statistical } \\
\text { and numerical } \\
\text { representation of } \\
\text { physical processes }\end{array}$ \\
\hline $\begin{array}{l}\text { Water utility long- } \\
\text { range planning }\end{array}$ & $\begin{array}{l}\text { How can downscaled climate } \\
\text { model data be effectively used } \\
\text { in long-term drought and water } \\
\text { system planning? }\end{array}$ & $\begin{array}{l}\text { Climate effects on } \\
\text { water supplies }\end{array}$ & $\begin{array}{l}\text { How can top-down and bottom- } \\
\text { up approaches be integrated } \\
\text { to identify and assess system- } \\
\text { specific sensitivities to climate } \\
\text { variability and change? }\end{array}$ & $\begin{array}{l}\text { Applicability and use } \\
\text { of climate models }\end{array}$ \\
\hline $\begin{array}{l}\text { Coastal habitat } \\
\text { vulnerability } \\
\text { assessment }\end{array}$ & $\begin{array}{l}\text { Which model output and } \\
\text { scenarios are best suited for the } \\
\text { Southeast? }\end{array}$ & $\begin{array}{l}\text { Climate effects on } \\
\text { coastal habitats }\end{array}$ & $\begin{array}{l}\text { Which methods are appropriate } \\
\text { for providing regionally- } \\
\text { specific information? }\end{array}$ & $\begin{array}{l}\text { Model skill } \\
\text { Communicating the } \\
\text { range of climate } \\
\text { scenarios }\end{array}$ \\
\hline $\begin{array}{l}\text { Freshwater } \\
\text { discharges in the } \\
\text { Edisto River }\end{array}$ & $\begin{array}{l}\text { How will possible, future } \\
\text { changes in Edisto River } \\
\text { discharge affect the blue crab } \\
\text { fishery? }\end{array}$ & $\begin{array}{l}\text { Climate effects on } \\
\text { streamflow, blue crab } \\
\text { abundance }\end{array}$ & $\begin{array}{l}\text { Is there an efficient way to } \\
\text { forecast changes in seasonal } \\
\text { streamflow that includes the } \\
\text { range of possible outcomes? }\end{array}$ & $\begin{array}{l}\text { Model choice } \\
\text { Unmeasured } \\
\text { watershed processes } \\
\text { Choice of climate } \\
\text { scenarios }\end{array}$ \\
\hline $\begin{array}{l}\text { Flooding regimes in } \\
\text { Congaree National } \\
\text { Park }\end{array}$ & $\begin{array}{l}\text { How will climate change affect } \\
\text { the riparian ecosystems at CNP? }\end{array}$ & $\begin{array}{l}\text { Climate effects on } \\
\text { hydrology, flood } \\
\text { inundation, and } \\
\text { species distribution }\end{array}$ & $\begin{array}{l}\text { How can we develop } \\
\text { streamflow simulation models } \\
\text { of highly managed watersheds } \\
\text { that facilitate investigation of } \\
\text { future climate scenarios? }\end{array}$ & Inteoration of climate \\
\hline $\begin{array}{l}\text { Salinity intrusion in } \\
\text { the Waccamaw River } \\
\text { and Winyah Bay }\end{array}$ & $\begin{array}{l}\text { How will changing water flows, } \\
\text { sea level rise, and salinity } \\
\text { conditions affect water resources in } \\
\text { coastal areas? } \\
\text { How might climate-induced } \\
\text { salinity changes affect the } \\
\text { distribution of the human } \\
\text { pathogenic bacteria, Vibrio spp? }\end{array}$ & $\begin{array}{l}\text { Climate effects } \\
\text { on drinking water } \\
\text { supply systems and } \\
\text { human health }\end{array}$ & $\begin{array}{l}\text { How can climate models be } \\
\text { integrated with other data } \\
\text { sources and tools? } \\
\text { What is the range of streamflow } \\
\text { responses to various future } \\
\text { climate scenarios? }\end{array}$ & $\begin{array}{l}\text { and hydrological } \\
\text { models } \\
\text { Model choice } \\
\text { "Cascading } \\
\text { uncertainties" }\end{array}$ \\
\hline
\end{tabular}

Grant Consortium, storm water managers, and university researchers, to develop a guide for low impact development (LID) in coastal South Carolina (Ellis et al., 2014). The LID guide developers questioned whether stationarity was a valid assumption for stormwater risk assessment and management given projected climate change and unique features of the coastal environment. They wanted to know the extent to which future climate conditions will affect water elevation, storm intensity, and storm duration and the implications for LID placement, design, and practices.
CISA was asked to provide input regarding climate change and precipitation intensity. Our role primarily involved participation in a Climate Stormwater Roundtable discussion in Charleston to outline literature and to present preliminary data analysis. Subsequent research by the LID guide team resulted in an Appendix dedicated to the topic of climate change and intense precipitation. The Appendix also provides information about observed and projected precipitation intensity changes in the region. It acknowledges uncertainty about future projections, and considers plausible 
changes relevant to stormwater drainage (Ellis et al., 2014). In particular, it notes that precipitation intensity changes cannot be projected accurately enough to inform specific design standards, but that planners can use a precautionary approach in their general designs to build resilience.

The time frame of the LID guide did not allow for a comprehensive analysis of long-term observations or climate model projections, but CISA has subsequently conducted both types of analysis. In one study, we identified spatial coherency in the observed and modeled patterns of intense precipitation in the Carolinas (Gao et al., 2015). This analysis assessed climate model bias in the region, as well as the range of projected changes in precipitation intensity. Nearly all projections show at least modest increases in precipitation intensity. A second study assessed historic changes in precipitation intensity at fourteen coastal weather stations in the Carolinas (Rodgers, 2015). While some of the changes at these stations are not consistent, analysis shows that the period of record consistently matters to analysis of these extreme events. This finding bears on decisions to use a full period of record vs. one that merely represents the most recent period.

\section{How can downscaled climate model data be effectively used in long-term drought and water system planning?}

In this ongoing project, CISA is assisting a water utility in North Carolina assess the potential effects of climate change on the long-term reliability of their water supply sources. The utility plans strategically for meeting water demands in the next 50 -year period using firm yield (the maximum quantity of water that can be supplied throughout the most extreme drought event observed) as a measure of reliability. As this approach does not consider potential risks associated with climate change, utility managers asked how downscaled climate model data can be incorporated into their planning process.

CISA is applying the decision-scaling approach (Brown et al., 2012) to develop and provide tailored climate change information to the water utility. This approach allows for tailoring multiple stages of the assessment to contextual information gained from the water resource managers. While we are using hydrologic and water-system models as in more conventional top-down approaches, here the methodological choices related to modeling the system's response to climate change are influenced by consultations with the utility representatives. This approach requires the use of several types and sources of climate data, including temperature and precipitation observations, open water evaporation data, USGS stream gage records, and climate change projections from the Coupled Model Intercomparison Project 5 (CMIP5) multi-model ensemble. ${ }^{2}$ The process also includes identifying water supply metrics and threshold levels that are consequential for strategic planning, for example infrastructure upgrades, inter-utility connections, or allocations from external water sources. We expect the potential changes to water supply reliability as projected by CMIP ensembles to span a wide range

\footnotetext{
${ }^{2}$ Information available at http://cmip-pcmdi.llnl.gov/cmip5/
}

given the uncertainty in the precipitation changes projected for the Southeast. One challenge is characterizing these uncertainties in a way that is useful for planning decisions. Hence, rather than simply communicating the changes as such, thresholds will be used to summarize the spread in water supply projections as relative likelihood of exceeding or not-exceeding critical thresholds.

\section{Which model output and scenarios are best suited for the Southeast?}

A team led by the North Inlet-Winyah Bay (SC) and Chesapeake Bay (VA) National Estuarine Research Reserves (NERR) received funding from the NERR System's Science Collaborative to develop the Climate Change Vulnerability Assessment Tool for Coastal Habitats (CCVATCH). ${ }^{3}$ This decision support tool was designed to assist refuge managers incorporate climate change into habitat vulnerability assessments. Project leads asked CISA to provide guidance regarding which general circulation model output and scenarios are best suited for the Southeast region and with which to assess habitat vulnerabilities.

There are two fundamental approaches to addressing this request. First, one could assess how well the models simulate climate variables during a "control period" (i.e., model output measured against historic climate observations). This approach assumes, however, that good model performance in the past translates into a more accurate projection for the future. For many climate variables, and at a regional scale, there is no guarantee that this is true (Klocke et al., 2011; Reifen and Toumi, 2009; Knutti, 2008). This hinders a scientist's ability to recommend, with certainty, one model over another. Therefore, a second approach is often adopted, wherein one examines the range of output from a suite of climate models. CISA recommended this second approach and used projections to summarize and depict the spread of temperature and precipitation changes. The primary products were regionally-specific boxplots of seasonal change in precipitation and average, maximum, and minimum temperature during 2040-2070 compared to the 1980-2010 control period. We also produced histograms and boxplots to show monthly changes for some variables. This information was provided to the CCVATCH team for their consideration as they developed climate change guidance for the tool.

Although CISA provided specific information derived from climate projections, the tool developers ultimately recommended a "bottom-up" approach and use of a variety of sources to assess habitat vulnerability. Methods include expert elicitation, site visits, literature reviews, and use of online tools that provide information about habitat conditions as well as climate model output (Plunket et al., 2015). Recognizing that much remains unknown or uncertain about climate change and its specific effects on the local level, the tool includes a "certainty" score to depict what aspects of the habitat assessment and knowledge base (e.g., expert opinion, research, or management reports) are more or less certain. In this way, experts identify and assess a habitat's linkages

\footnotetext{
${ }^{3}$ Information available at http://www.ccvatch.com/
} 
to climate and then use broadly available climate change information (e.g., the USGS National Climate Change Viewer $^{4}$ ) to inform their vulnerability assessment.

\section{How will possible, future changes in Edisto River discharge affect the blue crab fishery?}

Blue crabs are one of the most important commercial fisheries in the southeast, but landings have declined during recent droughts. Low levels of freshwater discharge into the estuary changes the salinity profile which influences crab growth, movement and survival (Childress and Parmenter, 2012). Given the sensitivity of blue crab populations on variable climate and streamflow conditions, there is also considerable interest in investigating the potential effects of climate change on the fishery. CISA is collaborating on an ongoing project to identify and examine a range of possible changes in Edisto River discharge that would affect salinity profiles and crab abundance (Childress, 2014).

CISA's contribution has focused on projecting future river discharge levels in response to climate change. An initial research design issue was determining which tool or model to use to simulate streamflow response. We used the Open-source Nonpoint Source Pollution and Erosion Comparison Tool (OpenNSPECT ${ }^{5}$ ) to simulate seasonal streamflow in the Edisto River watershed (Figure 1). To develop the streamflow projections, CISA acquired seasonal estimates of precipitation and evaporation for 2011-2030 from the Netherlands Meteorological Institute (KNMI) Climate Explorer website. ${ }^{6}$ To bracket the range of variability of climate projections we used the ensemble means for four Representative Concentration Pathways (RCPs), representing greenhouse gas concentration trajectories, used in CMIP5 analysis (RCP2.6, RCP4.5, RCP6.0, and RCP8.5; Taylor et al., 2012). This output drove discharge simulations. Results provided a range of possible discharge changes in the Edisto River through 2030. This information was used as input into a spatially explicit, individual-based blue crab population model parameterized for conditions in the ACE Basin National Estuarine Research Reserve to investigate potential effects on blue crabs. Model results suggested that considerable interannual variability in discharge will continue, but that annual river discharge will decline. Future crab landings are expected to increase or decline, depending on river discharge levels, but overall landings will decline if discharge also continues to decrease over time (Childress, 2015).

Project results are expected to be useful for resource managers at the coast who are dependent on river flow for the health of natural communities and ecosystems. As OpenNSPECT is a relatively straightforward watershed runoff simulation model that focuses on few parameters, there was a tradeoff that required us to account for important processes outside the model such as evapotranspiration. This highlights areas of uncertainty in the simulation results and

\footnotetext{
${ }^{4} \mathrm{http}: / /$ www.usgs.gov/climate_landuse/clu_rd/nccv/viewer.asp ${ }^{5} \mathrm{https}$ ://coast.noaa.gov/digitalcoast/tools/opennspect

${ }^{6} \mathrm{https}: / /$ climexp.knmi.nl/
}

suggests areas for additional research if more work is to be done on the overall question of Edisto River streamflow for downstream resource management.

\section{How will climate change affect the riparian ecosystems at Congaree National Park (CNP)?}

Park managers are interested in how future temperature (and evapotranspiration) increases and changing precipitation patterns could affect the hydrology, flood inundation, habitat connectivity, and species distribution at CNP by mid-century. CISA collaborated with a landscape ecologist and floodplain modeler to address these questions. The primary natural feature of CNP is the approximately $100 \mathrm{~km}^{2}$ floodplain of the Congaree River, a large alluvial river that begins in the Blue Ridge physiographic province. The Congaree River, which forms the southern boundary of the Park, merges with the Wateree River, which forms the eastern boundary. Both rivers contribute water to the floodplain during high flows (Figure 1). This ecosystem may be susceptible to climate change effects, especially changes in the hydrologic regime that may alter key ecosystem processes and functions.

CISA's role was to use watershed simulation models and downscaled GCM projections to develop several scenarios of mid-century streamflow. For the Congaree River watershed we used the Hydrologic Simulation Program-Fortran (HSPF) watershed simulation model (Bicknell et al., 2001), running as part of the Better Assessment Science Integrating point \& Non-point Sources (BASINS) modeling platform.?

For the Catawba-Wateree River watershed we also used HSPF and loosely coupled it with the Catawba-Wateree Computer Hydro-Electric Operations and Planning Software (CHEOPS ${ }^{\mathrm{TM}}$ ) operations model. CHEOPS was developed for Duke Energy to aid their most recent Federal Energy Regulatory Commission (FERC) relicensing process. These streamflow scenarios are being used in conjunction with a floodplain inundation model (see Kupfer et al., 2015) to investigate how future streamflow might affect flooding and park resources.

There are several challenges associated with the integration of climate model output with hydrologic models and many steps that add layers of uncertainty to modeling results. This approach involves modeling very complex hydroclimatological processes, processing downscaled climate model output for use in HSPF, and other significant data analysis and model testing. More specific to this project, both watersheds that form the streamflow source for CNP have reservoirs used for power generation. The Catawba River alone has eleven hydroelectric projects, making the streamflow in the upper two-thirds of the watershed highly managed. Dam operations are dynamic, based on rules that are conditionally variable based on several criteria, so modeling streamflow in regulated basins will have some inherent limitations. These complexities and uncertainties emphasize the need to interpret model results as possible responses to change in climate conditions, rather than actual numerical predictions.

\footnotetext{
${ }^{7}$ http://www.epa.gov/exposure-assessment-models/basins
} 
How will changing water flows and salinity conditions affect water resources in coastal areas?

In the Winyah Bay region, droughts and sea level rise have called resource manager attention to the concept that reduced flow of rivers at the coast can have a profound impact on their essential freshwater resource. To help municipal and industrial water supply managers assess the possible impact of future streamflow and sea level on the vulnerability of their surface water intakes to elevated salinity, CISA worked with the U.S. Geological Survey (USGS), Advanced Data Mining International, and South Carolina Sea Grant Consortium to develop a decision support system (DSS) (Conrads et al., 2013). CISA's role was to utilize HSPF models of the three main rivers that drain to the Winyah Bay to develop projections of mid-century streamflow (Figure 1). This was coupled with an Artificial Neural Network (ANN) model of salinity in the Waccamaw River and integrated into the Pee Dee River and Atlantic Intracoastal Waterway Salinity Model (PRISM) Version 2 DSS. The DSS consisted of a spreadsheet tool that allowed decision makers to estimate the number of days annually that salinity exceeded a threshold amount.

This project presented a unique set of challenges with respect to climate uncertainty. From a surface water salinity intrusion perspective, the variable of most concern is the co-occurrence of very low flows with spring high tides. The PRISM (Version 2) DSS included sea level rise (SLR) projections and tidal cycle information. Interim analysis of our results revealed that sea level elevation was a much stronger driver of salinity in the Waccamaw River than was streamflow. So for the final DSS we focused on a single GCM that represented a median range climate projection and included a range of SLR projections. Thus, our results depend on the level of confidence placed on the range of SLR estimates. This leaves unanswered the question of whether there are GCMs that, if used, may have projected streamflows with a significant enough impact on salinity along the longitudinal axis of the Waccamaw River to be considered. Our experience suggests the probability is relatively small but we cannot conclude that with certainty.

In a subsequent project, CISA worked with researchers at NOAA's Center for Coastal Environmental Health and Biomolecular Research (CCEHBR) to investigate how changing water flows and salinities might also affect environmental conditions and human health in the Waccamaw River. Public health researchers have noticed an increase in the range of some human pathogens that appears to be caused, in large part, by increasing temperatures of coastal oceans and estuaries (Baker-Austin et al., 2012). There has been interest in the increasing range and prevalence of Vibrio spp infections in the U.S. Southeast (Weis et al., 2011).

CISA collaborated with the CCEHBR to initiate field sampling in the Waccamaw River and laboratory analysis for the presence of Vibrio vulnificus and V. parahemolyticus. Field sampling along a transect that included a range of salinity from fresh to near sea water revealed a significant relationship between $V$. vulnificus and salinity. We then

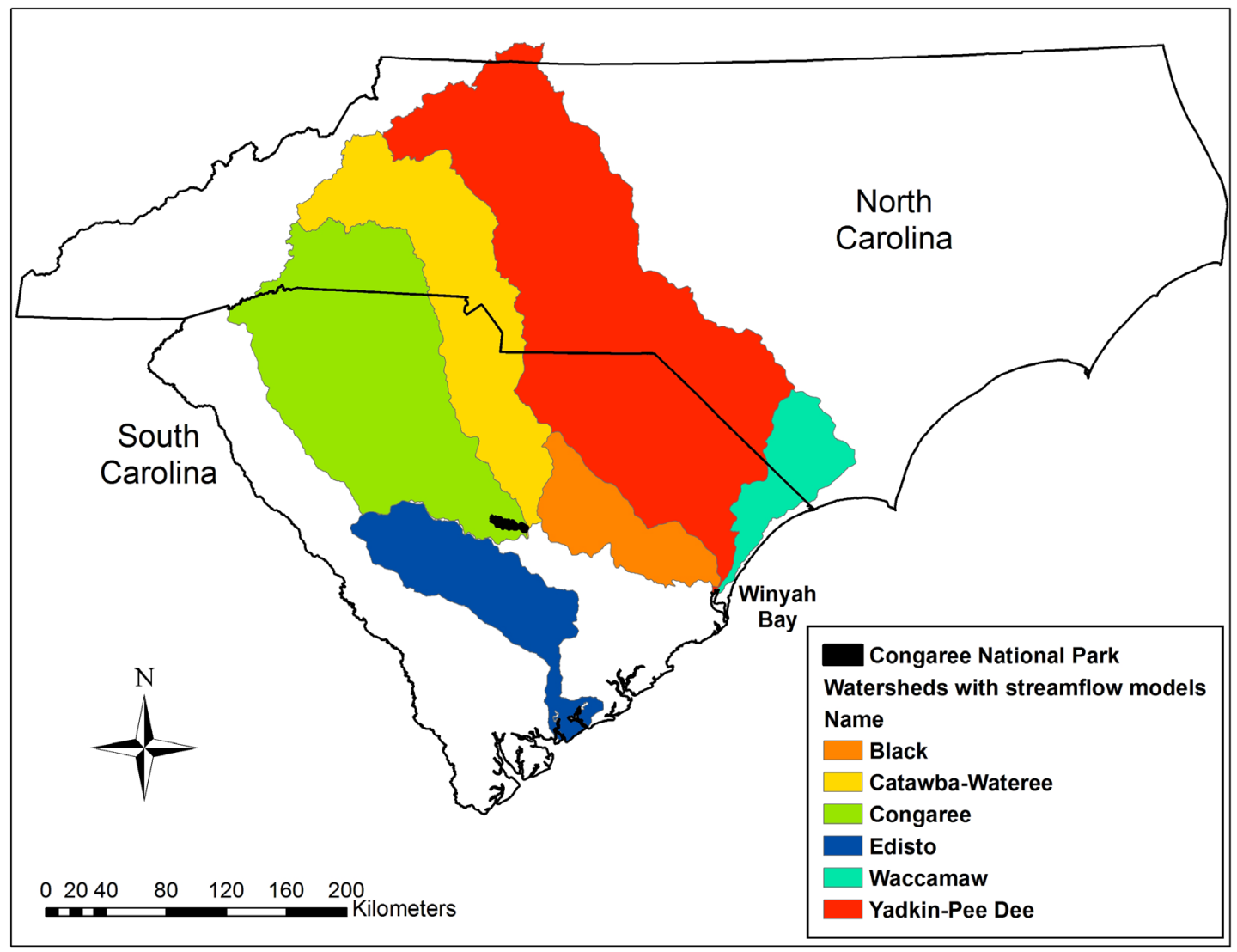

Figure 1. Watersheds modeled in CISA projects. 
utilized the PRISM (Version 2) DSS to investigate the potential increase in the occurrence of $V$. vulnificus due to elevated salinity in the Waccamaw River as a result of changes in streamflow and sea level (Deeb, 2013). The main effort in this project was to develop an empirical model of the concentration of $V$. vulnificus (hereafter $\mathrm{Vv}$ ) based on salinity. A range of salinities is optimal for $\mathrm{Vv}$ survival and growth. We then used the salinity projections from the PRISM (Version 2) DSS as the independent variable in the empirical model to project Vv concentrations. The salinity projections indicate that more of the river will have salinities that are within the optimal range for Vv. This work subsumes the uncertainty already described for the PRISM (Version 2) DSS. Additionally, we were able to sample for only one growing season so the empirical model does not take into account interannual variability or the interacting effects of temperature and perhaps other environmental factors that may reveal more about the strength of the salinity influence on $\mathrm{Vv}$ prevalence. Ongoing work is investigating the virulence of the Vv samples.

\section{DISCUSSION: DEVELOPING CLIMATE CHANGE GUIDANCE FOR THE CAROLINAS}

In the previous section we presented examples of specific decision-maker questions regarding the effects of climate change in the Carolinas and how to use climate change information for water resources planning and management. In our experiences, simple answers to decision-maker requests for climate change information are seldom available or appropriate. Given the complexities and uncertainties surrounding the climate system, and the many potential uses and needs for information, there are no "one-size-fits-all" solutions.

The narratives above illustrate that answering these questions often requires careful thinking about the problem, availability and qualities of existing information and tools, and design of new analyses or research when specific topics warrant further investigation. Table 2 summarizes, for the examples discussed in this paper, several of the issues a researcher or information provider should consider in developing climate change guidance. Each decisionmaker question or need typically is embedded in a unique context, with different priorities, interests, and stakeholders. Information requests and needs involve many different temporal and spatial scales, such as site-specific infrastructure, community-level water systems, and large watersheds. While the overarching question may be fairly universal (i.e., "how will climate change affect water resources?"), specific variables and processes vary from system to system.

Uncovering this type of information has required an iterative dialog with information users and decision makers (e.g., water managers), to improve CISA researchers' understanding of the physical system in question (e.g., a water utility), and climate-related information needs for pending short-term decisions as well as longer-range concerns. An important part of the process is clarifying the range of considerations and limitations involved in extracting relevant information from climate change projections. However, we also find that many decisions and questions would benefit from improved understanding and analyses of historical observations. Our observations parallel similar work that shows how multiple tools are often necessary to facilitate the incorporation of climate considerations into planning (e.g., Kotamarthi et al., 2016; Vogel et al., 2015). Here we provide some general guidance based on CISA's work to provide Carolinas-relevant climate information.

\section{Integrating Different Sources of Climate Information}

Decision-maker questions often center on which model output and scenarios should be used, particularly for the southeastern United States, and how to use model output effectively. In general, CISA's approach has been to recommend or use a combination of tools and approaches, rather than use climate model output exclusively. That said, many of the examples discussed here have required the construction of future climate change scenarios. While these scenarios can come from climate model projections, valuable information can also come from closer inspection of the historical record. When is one approach better than the other, and is it possible to blend these approaches? While the answers to these questions depend on the specific application, some general practices make sense.

For example, projections for the near future should draw on information derived from the historic record as much as possible. Interannual variability of most climate variables exceeds model-projected changes in the near term, and even the spread of model output. Likewise, for variables that are not well-modeled (e.g., precipitation intensity), the use of long-term instrumental records may provide more useful information, especially at local and regional scales. This highlights the importance of having robust local and historic information and building a better baseline understanding of past events and impacts. Such information can be used in conjunction with climate change models.

For projections later in the 21 st century, the use of an "ensemble" of climate models can capture the mean and variance associated with climate changes. Here, the strength of the models to capture climate response to increasing greenhouse gases can provide information not possible using historic observations. In some situations, a hybrid approach may be most appropriate, wherein interannual and interdecadal information from the historical record may be merged with the most consistent and robust climate model output.

Many of the examples discussed in this paper also highlight the importance of improving understanding of the system of concern itself, the linkages to climate, and the variables of greatest concern (Brown and Wilby, 2012; Snover et al. 2013). For example, investigations using long-term historic datasets and other tools provide valuable information regarding climate effects on forested wetlands in South Carolina's Coastal Plain (Chow et al., 2013; Dai et al., 2011; Dai et al., 2013). Such information is particularly important in systems where many different complex 
Table 2. Considerations when developing and using climate change information, from CISA examples.

\begin{tabular}{|c|c|c|c|c|}
\hline Project example & $\begin{array}{l}\text { Time horizon } \\
\text { of interest }\end{array}$ & $\begin{array}{l}\text { Spatial scale } \\
\text { of interest }\end{array}$ & CISA "products" & $\begin{array}{l}\text { Information and tools used } \\
\text { to answer question }\end{array}$ \\
\hline $\begin{array}{l}\text { Stormwater } \\
\text { management and } \\
\text { guidance for low } \\
\text { impact development } \\
\text { strategies in coastal } \\
\text { areas }\end{array}$ & Through 2100 & $\begin{array}{l}\text { Local } \\
\text { (low impact } \\
\text { development } \\
\text { sites) }\end{array}$ & $\begin{array}{l}\text { General guidance regarding use of climate } \\
\text { change information and expected changes } \\
\text { in precipitation intensity } \\
\text { Spin-off research to conduct more in- } \\
\text { depth investigation of questions related to } \\
\text { precipitation intensity }\end{array}$ & $\begin{array}{l}\text { Historical climate } \\
\text { observations } \\
\text { Climate model output }\end{array}$ \\
\hline $\begin{array}{l}\text { Water utility long- } \\
\text { range planning }\end{array}$ & $\begin{array}{l}2065 \\
\text { (utility's 50- } \\
\text { year planning } \\
\text { period) }\end{array}$ & $\begin{array}{l}\text { Local } \\
\text { (water } \\
\text { catchment, } \\
\text { utility service } \\
\text { area) }\end{array}$ & $\begin{array}{l}\text { Analyses (in process) that will show: } \\
\text { Potential changes to water supply } \\
\text { reliability } \\
\text { Relative likelihood of water supplies } \\
\text { exceeding/not exceeding critical } \\
\text { thresholds based on different climate } \\
\text { projections }\end{array}$ & $\begin{array}{l}\text { Historical hydroclimate } \\
\text { observations } \\
\text { Reservoir level records } \\
\text { Rainfall-runoff model } \\
\text { Utility operation model } \\
\text { Downscaled climate model } \\
\text { output }\end{array}$ \\
\hline $\begin{array}{l}\text { Coastal habitat } \\
\text { vulnerability } \\
\text { assessment }\end{array}$ & $2041-2070$ & $\begin{array}{l}\text { Regional to } \\
\text { local } \\
\text { (coastal habitats) }\end{array}$ & $\begin{array}{l}\text { Summaries and graphics from downscaled } \\
\text { climate projections }\end{array}$ & Climate model output \\
\hline $\begin{array}{l}\text { Freshwater } \\
\text { discharges in the } \\
\text { Edisto River }\end{array}$ & $2011-2030$ & $\begin{array}{l}\text { Regional (river } \\
\text { basin) }\end{array}$ & $\begin{array}{l}\text { Streamflow projections and model output } \\
\text { for use in an individual-based blue crab } \\
\text { model }\end{array}$ & $\begin{array}{l}\text { Downscaled climate model } \\
\text { output } \\
\text { Runoff and water quality } \\
\text { assessment tool }\end{array}$ \\
\hline $\begin{array}{l}\text { Flooding regimes in } \\
\text { Congaree National } \\
\text { Park }\end{array}$ & $2041-2070$ & $\begin{array}{l}\text { Regional (river } \\
\text { basin) }\end{array}$ & $\begin{array}{l}\text { Streamflow projections for the Congaree } \\
\text { and Catawba-Wateree River watersheds }\end{array}$ & $\begin{array}{l}\text { Downscaled climate model } \\
\text { output } \\
\text { Hydrologic model } \\
\text { Reservoir operation model }\end{array}$ \\
\hline $\begin{array}{l}\text { Salinity intrusion } \\
\text { in the Waccamaw } \\
\text { River and Winyah } \\
\text { Bay }\end{array}$ & $2041-2070$ & $\begin{array}{l}\text { Local } \\
\text { (river basin) }\end{array}$ & $\begin{array}{l}\text { Streamflow projections } \\
\text { Model output for use in the PRISM } \\
\text { (Version 2) DSS }\end{array}$ & $\begin{array}{l}\text { Downscaled climate model } \\
\text { output } \\
\text { Hydrologic models }\end{array}$ \\
\hline
\end{tabular}

processes interact, for example, reservoir, forest and forested wetlands management, as well as land use, prescribed burning, water withdrawals and discharges, and ecological processes. For many systems, not all scenarios will be appropriate. Having a strong base of knowledge about the system can help decision makers and researchers develop the most relevant and informative analyses for climate-related questions (Snover et al., 2013).

CISA's work in the Carolinas suggests that two particular factors influence the success of integrating future climate variability and change scenarios into water resource issues. First, how well understood are the connections between climate variables and the response of interest? Examples where sophisticated models link climate variables to a relevant impact have greater applicability than those that do not. In our case studies, the established inundation model for the Congaree National Park, the salinity prediction model for the Waccamaw River, and the crab growth and abundance model on the Edisto River illustrate how climate change scenarios, even with uncertainty, can help identify a reasonable range of potential impacts. Second, what is the level of uncertainty associated with the climate variables that matter most? The consistency of future projections of annual, and even seasonal, temperature instills far greater confidence, for example, than those of precipitation intensity where empirical and modeled scenarios are less consistent. The collaborative process between researchers and decision makers aids in reconciling these two questions by sharing information about the links between climate and physical/ human systems, and the uncertainty associated with projections of the most relevant climate variables.

\section{Answering Questions Regarding Climate Change Effects on the Watershed Scale}

CISA's primary approach has been to integrate downscaled climate model output with hydrological models. Here we summarize some of the challenges associated with this approach and our ability to assess climate impacts at that scale.

One of the main sources of uncertainty from the perspective of simulating future streamflow relates to the projected changes in precipitation; hindcasting to compare the historic precipitation record with GCM simulations shows limited skill and wide variability among GCMs (Hwang et al., 2013; Sobolowski and Pavelsky, 2012). Nonetheless the GCM projections provide the 
best information available about future scenarios, so it is incumbent upon the science community to provide stakeholders with defensible and relevant information using these data.

This leads to two essential aspects of using GCM model output to assess potential impacts on water resources. First, we must sample the variability in climate change projections adequately to provide streamflow response to various combinations of hot/warm and wet/dry conditions. This would allow stakeholders to assess their options for a range of possible outcomes. Second, we must communicate to decision makers our results do not represent absolute predictions. For example, we do not know what precipitation will be like in the future but we can demonstrate the effects of changing precipitation using the best science and data currently available. Alternatively, we cannot say that mean stream discharge will be a particular value at some future date. Rather, given the conditions represented in the hydrologic models and the climate projections, stream discharge appears to respond in a particular direction (increase, decrease, no change) at a particular rate. Some uncertainty associated with GCMs can also be reduced by focusing on the most realistic projections of greenhouse gas concentrations (i.e., as represented in the RCPs). For example, projections derived from unrealistic emissions trajectories could be eliminated (Snover et al., 2013).

Another major source of uncertainty in future streamflow is the effect of land use and water management changes. It is well known that certain kinds of land use change, for example converting a large percentage of pervious to impervious surfaces, can dramatically affect streamflow within individual catchments. At the scale of very large watersheds that are predominantly rural with little chance of widespread change over several decades, it is unclear how significant the effect will be. A simplifying assumption in our work thus far is that we can ignore land use change at these scales. However, it is a research question we are currently investigating.

\section{CONCLUSION: ADVANCING THE CLIMATE CHANGE DIALOGUE}

CISA's experiences, as well as those from similar programs and efforts to better integrate climate science and on-the-ground decisions, offer insights for advancing the dialogue around climate information needs in the Carolinas. Increasing decision-maker interest in pursuing climate change questions provides opportunities to develop and refine the processes necessary to integrate top-down and bottom-up approaches, tools, and information. On one hand, decision-maker questions often reveal new topics to be examined, thereby informing CISA's applied research program. However, there is still much to be done to bridge the gaps between decision making questions and needs and the ability of climate science and research to provide useful and usable information. CISA's, and related, research suggest several important components of this process.
First, ongoing and future efforts will require iterative engagement between researchers and information users. Twoway, long-term, communications and interactions between climate researchers and information users is essential. Linear, one-way information dissemination from producers to users is unlikely to yield relevant information for decisions. Communication must occur early in the research design process and incorporate ongoing feedback from decision makers about their use and needs for climate information (Lemos and Morehouse, 2005; Vogel et al., 2015).

Second, both scientists and decision makers should have the willingness, and capacity, to innovate and experiment with new approaches. This includes the design of research that is shaped by scientists in collaboration with resource managers or policy makers (McNie et al., 2016; Parris et al., 2016). It also includes water management and planning approaches that are open to developing new methods to increase resilience and improve system flexibility to adapt to future climate variability and change (Brown, 2010; Kiparskey et al., 2012; Vogel et al., 2015).

Finally, collaboration between different groups can also be viewed as "experiments" and essential learning opportunities (Parris et al., 2016). These points are important as CISA works to help different audiences better understand the climate system, how it affects our region, and what tools and resources are most appropriate for assessing risks and vulnerabilities. The continued development of improved scientific and technical information, as well as innovative processes to develop, provide, and use information, will be a necessity as the region works to enhance its climate resilience.

\section{ACKNOWLEDGMENTS}

Work discussed here has been conducted through the Carolinas Integrated Sciences \& Assessments (CISA) program and supported by the National Oceanic and Atmospheric Administration (NOAA) Climate Program Office (grant no. NA11OAR4310148). 


\section{LITERATURE CITED}

Baker-Austin, C., J.A. Trinanes, N.G.H. Taylor, R. Hartnell, A. Siitonen, and J. Martinez-Urtaza, 2012. "Emerging Vibrio risk at high latitudes in response to ocean warming." Nature Climate Change 3:73-77.

Barsugli.J.J., J.M. Vogel, L. Kaatz, J.B. Smith, M. Waage, and C.J. Anderson. 2012. Two Faces of Uncertainty: Climate Science and Water Utility Planning Methods. Journal of Water Resources Planning and Management 138(5):389-395.

Bicknell, B.R., J. C. Imhoff, J.L. Kittle Jr, A. S. Donigian, and R. Johanson, 2001. Hydrologic Simulation

Program-Fortran User's Manual for Release 12. Exposure Research Laboratory, Office of Research and Development, US Environmental Protection Agency, Athens, Georgia.

Briley, L., D. Brown, and S.E. Kalafatis, 2015. Overcoming barriers during the co-production of climate information for decision-making. Climate Risk Management 9:41-49. Brown, C., 2010. The End of Reliability. Journal of Water Resources Planning and Management 136 (2):143-145.

Brown, C. and R.L. Wilby, 2012. An Alternate Approach to Assessing Climate Risks. Eos 93 (41):401-412.

Brown, C., Y. Ghile, M. Laverty, and K. Li, 2012. Decision scaling: Linking bottom-up vulnerability analysis with climate projections in the water sector. Water Resources Research 48:W09537. doi: 10.1029/2011WR011212

Carbone, G.J., 2014. Managing climate change scenarios for societal impact studies. Physical Geography 35 (1):22-49.

Childress, M., 2014. Going with the flow: Forecasting the impact of climate change on blue crabs. Proceedings of the 2012 South Carolina Water Resources Conference, October 15-16, 2014, Columbia, SC.

Childress, M., 2015. Forecasting a crab fishery using realtime freshwater flow data. Dry Times 5 (2):5-6.

Childress, M. and K.J. Parmenter, 2012. Dying of Thirst: Impact of Reduced Freshwater Inflow on South Carolina Blue Crabs. Proceedings of the 2012 South Carolina Water Resources Conference, October 10-11, 2012, Columbia, SC.

Chow, A.T., J. Dai, W.H. Conner, D.R. Hitchcock, and J.J. Wang. 2013. Dissolved organic matter and nutrient dynamics of a coastal freshwater forested wetland in Winyah Bay, South Carolina. Biogeochemistry 112:571-587.

Conrads, P.A., E.A. Roehl, Jr., R.C. Daamen, and J.B. Cook, 2013. Simulation of salinity intrusion along the Georgia and South Carolina coasts using climate-change scenarios. Scientific Investigations Report 2013-5036, U.S. Geological Survey.
Dai, Z., D. M. Amatya, G. Sun, C.C. Trettin, C. Li, and H. Li. 2011.Climate Variability and Its Impact on Forest Hydrology on South Carolina Coastal Plain, USA. Atmosphere 2:330-357.

Dai, Z., C.C. Trettin, C. Li, G. Sun, D.M. Amatya, and H. Li. 2013. Modeling the impacts of climate variability and hurricane on carbon sequestration in a coastal forested wetland in South Carolina. Natural Science 5 (3):375-388.

Deeb, R., 2013. Climate Change Effects on Vibrio Bacteria in the Winyah Bay Estuary and the Projected Spread of Vibrio under Future Climatic Scenarios. Master's thesis, University of South Carolina, Columbia, SC.

Dessai, S. and M. Hulme, 2007. Assessing the robustness of adaptation decisions to climate change uncertainties: A case study on water resources management in the East of England. Global Environmental Change 17:59-72.

Dilling, L. and M.C. Lemos, 2011. Creating usable science: Opportunities and constraints for climate knowledge use and their implications for science policy. Global Environmental Change 21 (2):680-689.

Dow, K., R.L. Murphy, and G.J. Carbone, 2009. Consideration of User Needs and Spatial Accuracy in Drought Mapping. Journal of the American Water Resources Association 45 (1):187-197.

Ellis, K., C. Berg, D. Caraco, S. Drescher, G. Hoffmann, B. Keppler, M. LaRocco, and A. Turner, 2014. Low Impact Development in Coastal South Carolina: A Planning and Design Guide. ACE Basin and North Inlet - Winyah Bay National Estuarine Research Reserves.

Gao, P., G.J. Carbone, and D. Guo, 2015. Assessment of NARCCAP model in simulating rainfall extremes using a spatially constrained regionalization method. International Journal of Climatology 36:2368-2378. doi: $10.1002 /$ joc. 4500

Hwang, S., W.D. Graham, A. Adams, and J. Geurink, 2013. Assessment of the utility of dynamically-downscaled regional reanalysis data to predict streamflow in west central Florida using an integrated hydrologic model. Regional Environmental Change 13:S69-S80. doi: 10.1007/s10113-013-0406-x

Ingram, K., K. Dow, L. Carter, and J. Anderson, eds., 2013. Climate of the Southeast United States: Variability, Change, Impacts, and Vulnerability. Washington DC: Island Press.

Jacob, D., J. Petersen, B. Eggert, A. Alias, et al., 2014. EURO-CORDEX: new high-resolution climate change projections for European impact research. Regional Environmental Change 14 (2):563-578. doi: 10.1007/ s10113-013-0499-2

Kiparsky, M., A. Milman, and S. Vicuña, 2012. Climate and Water: Knowledge of Impacts to Action on Adaptation. Annual Review of Environment and Resources 37:163-194. 
Klocke, D., R. Pincus, and J. Quaas, 2011. On constraining estimates of climate sensitivity with present-day observations through model weighting. Journal of Climate 24:6092-6099. doi:10.1175/2011JCLI4193.1

Knutti, R., 2008. Should we believe model predictions of future climate change? Philosophical Transactions of the Royal Society 366:4647-4664. doi:10.1098/ rsta.2008.0169

Kotamarthi, R., L. Mearns, K. Hayhoe, C.L. Castro, and D. Wuebble, 2016. Use of Climate Information for DecisionMaking and Impacts Research: State of Our Understanding. Prepared for the Department of Defense, Strategic Environmental Research and Development Program.

Kupfer, J.A., K.M. Meitzen, and P. Gao, 2015. Flooding and surface connectivity of Taxodium-Nyssa stands in a southern floodplain forest ecosystem. River Research and Applications 31:1299-1310.

Lackstrom, K., N.P. Kettle, B. Haywood, and K. Dow, 2014. Climate-Sensitive Decisions and Time Frames: A Cross-Sectoral Analysis of Information Pathways in the Carolinas. Weather, Climate, and Society 6:238-252.

Lemos, M.C. and B.J. Morehouse, 2005. The co-production of science and policy in integrated climate assessments. Global Environmental Change 15:57-68.

Lemos, M C. and R.B. Rood, 2010. Climate projections and their impact on policy and practice. WIREs Climate Change 1:670-682.

McNie, E.C., A. Parris, and D. Sarewitz, 2016. Improving the public value of science: A typology to inform discussion, design and implementation of research. Research Policy 45:884-895.

Mearns, L.O., R. Arritt, S. Biner, M.S. Bukovsky, et al., 2012. The North American Climate Change Assessment Program: Overview of Phase I Results. Bulletin of the American Meteorological Society 93 (9):1337-1362.

Milly, P.C.D., J. Betancourt, M. Falkenmark, R.M. Hirsch, Z.W. Kundzewicz, D.P. Lettenmaier, and R.J. Stouffer, 2007. Stationarity is Dead: Whither Water Management? Science 319:573-574. doi: 10.1126/science.1151915

Moss, R., P.L. Scarlett, M.A. Kenney, H. Kunreuther, et al., 2014. Decision Support: Connecting Science, Risk Perception, and Decisions. Climate Change Impacts in the United States: The Third National Climate Assessment, J. M. Melillo, Terese (T. C.) Richmond, and G.W. Yohe, Eds., U. S. Global Change Research Program, 620-647. doi: 10.7930/JOH12ZXG

Mote, P.W., M.R. Allen, R.G. Jones, S. Li, R. Mera, D.E. Rupp, A. Salahuddin, and D. Vickers, 2016. Superensemble Regional Climate Modeling for the Western United States. Bulletin of the American Meteorological Society 97 (2):203-215. doi: 10.1175/ BAMS-D-14-00090.1
Nagy, R.C., B.G. Lockaby, B. Helms, L. Kalin, and D. Stoeckel, 2011. Water Resources and Land Use and Cover in a Humid Region: The Southeastern United States. Journal of Environmental Quality 40:867-878.

NRC (National Research Council), 2009. Informing Decisions in a Changing Climate. Panel on Strategies and Methods for Climate-Related Decision Support, Committee on the Human Dimensions of Global Change. Division of Behavioral and Social Sciences and Education. Washington, DC: The National Academies Press.

Parris, A.S., G.M. Garfin, K. Dow, R. Meyer, and S.L. Close, eds., 2016. Climate in Context: Science and Society Partnering for Adaptation. West Sussex, UK: John Wiley \& Sons Ltd.

Pidgeon, N. and B. Fischhoff, 2011. The role of social and decision sciences in communicating uncertain climate risks. Nature Climate Change 1: 35-41. http://www. nature.com/doifinder/10.1038/nclimate 1080

Plunket, J., K. Stanzel, R. Weber, and S. Lerberg, 2015. Climate Change Vulnerability Assessment Tool for Coastal Habitats: Guidance Documentation. http://www. ccvatch.com

Reifen, C., and R. Toumi, 2009. Climate projections: Past performance no guarantee of future skill? Geophysical Research Letters 36, L13704. doi: 10.1029/2009GL038082

Rodgers, K.G., 2015. Sensitivity of Temporal Variability and Trends in Design Storm Rainfall Estimates to Selection of the Observed Record. Master's project, University of South Carolina, Columbia, SC.

Sanger, D., A. Blair, G. DiDonato, T. Washburn, et al., 2015. Impacts of Coastal Development on the Ecology of Tidal Creek Ecosystems of the US Southeast Including Consequences to Humans. Estuaries and Coasts 38 (Supplement 1):S49-S66.

SC DNR (South Carolina Department of Natural Resources). 2014. South Carolina's State Wildlife Action Plan (SWAP) 2015. Columbia, SC.

Snover, A.K., N.J. Mantua, J.S. Littell, M.A. Alexander, M.M. McClure, and J. Nye, 2013. Choosing and Using Climate-Change Scenarios for Ecological-Impact Assessments and Conservation Decisions. Conservation Biology 27 (6):1147-1157.

Sobolowski, S. and T. Pavelsky, 2012. Evaluation of present and future North American Regional Climate Change Assessment Program (NARCCAP) regional climate simulations over the southeast United States. Journal of Geophysical Research-Atmospheres 117(D1):1101. doi: 10.1029/2011JD016430 
Stainforth, D.A., T.E. Downing, R. Washington, A. Lopez, and M. New, 2007. Issues in the interpretation of climate model ensembles to inform decisions. Philosophical Transactions of the Royal Society of London A:

Mathematical, Physical and Engineering Sciences 1857: 2163-2177.

Taylor, K.E., R.J. Stouffer, and G.A. Meehl, 2012. An overview of CMIP5 and the experiment design. Bulletin of American Meteorological Society 93:485-498. doi: 10.1175/BAMS-D-11-00094.1

Terando, A.J., J. Costanza, C. Belyea, R.R. Dunn, A. McKerrow, and J.A. Collazo, 2014. The southern megalopolis: Using the past to predict future of urban sprawl in the Southeast U.S. PLOS ONE 9 (7):e102261. doi: 10.1371/journal.pone. 0102261

Travis, W.R. and B. Bates, 2014. What is climate risk management? Climate Risk Management 1:1-4.

USDA (United States Department of Agriculture). 2015. Francis Marion National Forest Draft Revised Land Management Plan. USDA Forest Service, Columbia SC. Vogel, J.M., J.B. Smith, M. O'Grady, P. Fleming, K. Heyn, A. Adams, D. Pierson, K. Brooks, and D. Behar, 2015. Actionable Science in Practice: Co-producing Climate Change Information for Water Utility Vulnerability Assessments. Final Report of the Piloting Utility Modeling Applications (PUMA) Project. http:// www.wucaonline.org/assets/pdf/pubs_puma_white_ paper_2015_04_27.pdf

Weaver, C., R. Lempert, C. Brown, J. Hall, D. Revell, and D. Sarewitz, 2013. Improving the contribution of climate model information to decision making: the value and demands of robust decision frameworks. WIREs Climate Change 4 (1):39-60. doi: 10.1002/wcc.202

Weis, K.E., Hammond, R.M., R. Hutchinson, and C.G.M. Blackmore, 2011. Vibrio illness in Florida, 1998-2007. Epidemiology and Infection. 139 (4):591-598.

Wilby, R.L. and S. Dessai, 2010. Robust adaptation to climate change. Weather 65 (7):180-185. 